\title{
Perancangan Enterprise Arsitektur Sistem Informasi Manajemen Aset Menggunakan Kerangka Zachman pada RSJ Daerah Dr. Amino Gondohutomo Semarang
}

\author{
Fitri Febriani $^{1}$, Indra Gamayanto ${ }^{2}$, Sasono Wibowo ${ }^{3}$ \\ Universitas Dian Nuswantoro, Imam Bonjol 207 \\ Program Studi Sistem Informasi \\ e-mail: ${ }^{1}$ fitrifebbriani01@gmail.com, ${ }^{2}$ indra.gamayanto@dsn.dinus.ac.id, \\ ${ }^{3}$ sasono.wibowo@dsn.dinus.ac.id
}

Diterima: 19 Februari 2021; Direvisi: 9 Mei 2021; Disetujui: 17 Mei 2021

\begin{abstract}
Abstrak
Rumah Sakit Jiwa Daerah (RSJD) Dr. Amino Gondohutomo Semarang merupakan salah satu rumah sakit jiwa kelas A sebagai pusat rujukan pelayanan kesehatan jiwa bagi masyarakat Jawa Tengah. Timbulnya berbagai permasalahan dan kendala yang dihadapi terutama dalam hal manajemen aset yang masih belum optimal yaitu besarnya ruang lingkup RSJD Dr. Amino Gondohutomo mengakibatkan sering terjadinya peminjaman ataupun perpindahan aset yang tidak dapat diketahui oleh perusahaan. Tidak adanya sistem informasi manajemen aset yang terintegrasi antar bagian terkait, menyebabkan informasi yang diberikan relatif lambat untuk dilakukan koreksi serta pengawasan terhadap aset yang ada sehingga menyebabkan tidak ada kejelasan atau kesesuaian informasi terkait monitoring terhadap data aset dan proses distribusi aset, maka tidak jarang jika terjadi ketidaksesuaian antara sumber data dan bukti fisik di lapangan. Dari beberapa permasalahan yang timbul jika tidak segera ditangani maka akan mengakibatkan kerugian dan berdampak negatif pada perusahaan itu sendiri. Oleh karena itu penelitian ini bertujuan untuk menciptakan model blueprint rancangan enterprise architecture menggunakan metode kerangka Zachman yang diharapkan dapat digunakan sebagai acuan dalam membangun prototype sistem informasi manajemen aset RSJD. Dr. Amino Gondohutomo. Dengan adanya penelitian ini diharapkan dapat memberikan kemudahan bagi RSJD. Dr. Amino Gondohutomo dalam melakukan manajemen aset sehingga bisa lebih optimal. Kerangka zachman merupakan metode yang paling tepat karena memiliki tiga puluh enam sel yang secara details dapat mengatasi permasalahan yang terdapat pada RSJD. Dr. Amino Gonohutomo.
\end{abstract}

Kata kunci: Enterprise Architecture, Blueprint IT, Metode Kerangka Zachman, Sistem Informasi Manajemen

\begin{abstract}
Regional Mental Hospital (RSJD) Dr. Amino Gondohutomo Semarang is a class A mental hospital as a referral center for mental health services for the people of Central Java. The emergence of various problems and obstacles faced, especially in terms of asset management that is still not optimal, namely the enormous scope of RSJD Dr. Amino Gondohutomo results in frequent lending or transfer of assets that the company cannot know. The absence of an integrated asset management information system between related sections causes the information provided is relatively slow to be corrected and supervised the existing assets so that there is no clarity or suitability of information related to the monitoring of asset data and asset distribution processes, it is not uncommon if it occurs mismatch between data sources and physical evidence in the field. Of the several problems that arise if not addressed immediately, it will result in losses and harm the company itself. Therefore, this study aims to create a blueprint model of enterprise
\end{abstract}


architecture design using the Zachman framework method, which is expected to use as a reference in building the prototype of the RSJD asset management information system. Dr. Amino Gondohutomo. This research is expected to provide convenience for the RSJD. Dr. Amino Gondohutomo in carrying out asset management so that it can be optimized. Zachman framework is the most appropriate method because it has thirty-six cells that can in detail solve the problems found in RSJD. Dr. Amino Gonohutomo.

Keywords: Enterprise Architecture, IT Blueprint, Zachman Farmework Method, Asset Management Information System

\section{PENDAHULUAN}

Pada saat ini kita berada di zaman revolusi industry yang disebut sebagai revolusi industry 4.0. Hal ini dapat diartikan bahwa sebuah konsep revolusi teknologi yang berbasis pada komunikasi yang saling terhubung satu sama lain sehingga dapat memungkinkan terjadinya pertukaran informasi secara lebih cepat dan hal ini memiliki tiga hal penting yaitu manusia dengan manusia, manusia dengan mesin dan mesin dengan mesin [1]. Oleh karena itu, industri 4.0 merupakan sebuah tantangan yang harus direspon secara cepat dan hal ini menuntut organisasi, perusahaan dan instansi untuk melakukan perubahan dalam informasi, data dan kecepatan serta akurasi yang akurat dan tepat [2], [3]. Pada penelitian ini, rumah sakit ini merupakan rujukan pelayanan kesehatan jiwa bagi masyarakat dengan memanfaatkan teknologi informasi sebagai salah satu pendukung dalam melaksanakan kegiatannya dan ini merupakan asset penting yang dimiliki dalam menjalankan operasional [4], [5]. Kita ketahui bahwa aset merupakan salah satu hal penting yang dimiliki oleh organisasi/perusahaan/instansi, dalam hal ini rumah sakit harus memiliki aset yang bermanfaat dan pengelolaan yang efektif dan efesien sehingga dapat menjalankan proses bisnis yang terdapat di dalamnya [6], [7].

Pengelolaan aset pada rumah sakit menjadi lebih penting lagi, karena hal ini akan dapat meningkatkan pengawasan pergerakan aset yang mendukung aset operasional yang sedang berlangsung di dalamnya. Seiring dengan berkembangkan globalisasi, rumah sakit melakukan perubahan, tetapi beberapa aset lama dan aset baru masih ada yang berjalan bersamaan agar perubahan tersebut dapat diadaptasi secara bertahap oleh para staff [8], [9]. Masalah seperti terdapatnya input data yang berulang harus segera diatasi, proses penyimpanan data serta proses rekap lainnya juga merupakan salah faktor penting yang harus segera diatasi, karena hal ini akan dapat menghambat perubahan yang lebih baik [10], [11]. Oleh karena itu, walaupun sudah terdapat teknologi informasi sebagai pendukung utama dalam perubahan, beberapa hal seperti pendataan, penempatan, peminjaman dan mutase aset harus secara details dilakukan perubahan agar rumah sakit dapat menjadi lebih baik lagi dalam pelayanan dan proses-proses di dalamnya dapat berjalan secara sistematis dan terstruktur dengan sangat baik. Dari permasalahan tersebut, kita dapat melihat dibutuhkan solusi dan metode yang digunakan adalah kerangka Zachman, beberapa alasan penting mengapa kerangka Zachman dipilih untuk mengatasi masalah di rumah sakit tersebut adalah: mengkategorikan dengan mendetails aspek sistem perusahaan/organisasi ke dalam bentuk matriks serta berhubungan dengan lingkungan bisnis yang lebih spesifik. [12], [13], [14]. Mendetails dan spesifik artinya metode ini dapat mendetailkan hal-hal apa saja yang seharusnya dilakukan terlebih dahulu atau dengan kata lain prioritas apa saja yang menjadi dasar utama dalam mengatasi permasalahan yang terdapat di dalam rumah sakit, yang kemudian menghungkannya dengan lingkungan bisnis serta realitas yang terjadi sehingga terdapat solusi yang tepat sasaran.

\section{METODE PENELITIAN}


Gambar 1 menjelaskan proses penelitian pada rumah sakit, dimana pada tahap pertama dokumen serta penelitian lain dijadikan sebagai materi referensi utama dalam mengembangkan solusi yang tepat, dan metode apa yang tepat dalam mengatasi permasalahan tersebut.

Studi literatur; Observasi; Wawancara; Analisis masalah
Kerangka Zachman; Analisis \& implementasi Zachman pada RSJD Dr. Amino Gondohutomo
Blueprint IT Sistem Informasi Manajemen Aset

Gambar 1. Proses penelitian

Setelah dilakukan analisis mendalam maka, ditentukan kerangka Zachman merupakan hal yang tepat. Adapun kelebihan dari kerangka Zachman antara lain: (1) kerangka Zachman memiliki standard de facto dalam mengklasifikakan secara tepat enterprises arsitecture, (2) struktur logika pada kerangka Zachman dapat lebih spesifik dalam mengatasi permasalahan perspektif manajemen dan bisnis atau sebuah proses bisnis, (3) kerangka Zachman menggambarkan sebuah konstruktusi pararel yang sistematis dan terstruktur dalam penerapannya, (4) kerangka Zachman dapat melakukan maturity level dalam mengatasi permasalahan yang ada. Tahap berikutnya adalah dengan melakukan obserivasi langsung di rumah sakit, melakukan wawancara. Tahap kedua adalah analisis dan penerapan kerangka Zachman untuk mengatasi permasalahan yang ada, dan tahap ketiga yang merupakan tahap akhir adalah blueprint dan/atau rekomendasi proses yang dapat digunakan untuk mengatasi permasalahan tersebut serta memberikan solusi. Proses-proses tersebut dapat ditunjukan pada gambar 2 berikut:

\begin{tabular}{|c|c|c|c|c|c|c|}
\hline & What & How & Where & Who & When & Why \\
\hline $\begin{array}{l}\text { Perspektif Planner } \\
\text { (Scope) }\end{array}$ & $\begin{array}{c}\text { Data-data penting } \\
\text { RSIO DrAmino } \\
\text { Gondohutomo berkaitan } \\
\text { dengan pengelolaan } \\
\text { barang }\end{array}$ & $\begin{array}{c}\text { Identifasi proses } \\
\text { bisnis manajemen aset } \\
\text { barang sebelum dan } \\
\text { sesudah ada sistem } \\
\text { informasi }\end{array}$ & $\begin{array}{l}\text { Peta lokasi bisnis } \\
\text { RSJD Dt Amino } \\
\text { Gondohutomo }\end{array}$ & $\begin{array}{l}\text { Pihak-pihak penting } \\
\text { yang teribat dalam } \\
\text { proses bisnis }\end{array}$ & $\begin{array}{c}\text { Avtivitas penting } \\
\text { berkaitan dengan } \\
\text { proses bisnis } \\
\text { pengelolaan barang }\end{array}$ & $\begin{array}{l}\text { Visi dan Misi } \\
\text { RS.JD De Amino } \\
\text { Gondobutomo }\end{array}$ \\
\hline $\begin{array}{l}\text { Perspektif Owner } \\
\text { (Business Model) }\end{array}$ & $\begin{array}{c}\text { Mendeskripsikan } \\
\text { bagaimana alur } \\
\text { Business Process } \\
\text { Model and Notation } \\
\text { (BPMN) }\end{array}$ & $\begin{array}{c}\text { Penggambaran } \\
\text { BPMN alur proses } \\
\text { yang terjadi saat ini }\end{array}$ & $\begin{array}{l}\text { Denah Gedung PDE } \\
\text { RS.JD Dr. Amino } \\
\text { Gondohutomo }\end{array}$ & \begin{tabular}{|} 
SDM yang terlibat \\
untuk membangun \\
dan mengelola sistem
\end{tabular} & $\begin{array}{c}\text { Time schedule } \\
\text { proyek pembangunan } \\
\text { sistem }\end{array}$ & $\begin{array}{c}\text { Targethujuan } \\
\text { pengadaan sistem }\end{array}$ \\
\hline $\begin{array}{l}\text { Perspektif Designer } \\
\text { (System Mlodels) }\end{array}$ & $\begin{array}{c}\text { Rancangan Use Case } \\
\text { Sistem dan Class } \\
\text { Diagram }\end{array}$ & $\begin{array}{c}\text { Rancangan Sicenario } \\
\text { Use Case, Activity } \\
\text { Diagram, } \\
\text { dan Sequence } \\
\text { Diagram }\end{array}$ & $\begin{array}{l}\text { Gambar desain } \\
\text { jaringan sistem }\end{array}$ & $\begin{array}{l}\text { Gambar desain } \\
\text { input-output sistem }\end{array}$ & $\begin{array}{c}\text { Detail time schedule } \\
\text { perancangan model } \\
\text { sistem }\end{array}$ & $\begin{array}{l}\text { Batasan/aturan } \\
\text { perancangan } \\
\text { model sistem }\end{array}$ \\
\hline $\begin{array}{l}\text { Perspektif Builder } \\
\text { (Technology Physics) }\end{array}$ & $\begin{array}{l}\text { Deskripsi arsiteitur } \\
\text { jaringan teknologi } \\
\text { yang akan digunakan }\end{array}$ & $\begin{array}{l}\text { Diagram alur } \\
\text { keseluruhan proses } \\
\text { fisk sistem }\end{array}$ & $\begin{array}{l}\text { Gambar desain } \\
\text { arsitektur jaringan } \\
\text { teknologi }\end{array}$ & $\begin{array}{c}\text { Gambar implementasi } \\
\text { antarmuka } \\
\text { (orototype) sistem }\end{array}$ & $\begin{array}{c}\text { Detail time schedule } \\
\text { pembangunan model } \\
\text { sistem }\end{array}$ & $\begin{array}{l}\text { Batasan/aturan } \\
\text { perancangan } \\
\text { desain sistem }\end{array}$ \\
\hline $\begin{array}{l}\text { Perspektif } \\
\text { Subcontractor } \\
\text { (Detai Representabion) }\end{array}$ & $\begin{array}{l}\text { Deskripsi rich picture } \\
\text { masing-masing } \\
\text { proses bisnis utama } \\
\text { sistem informasi } \\
\text { manajemen aset }\end{array}$ & $\begin{array}{l}\text { Penggambaran Rich } \\
\text { Picture proses sistem } \\
\text { informasi manajemen } \\
\text { aset setelah adanya } \\
\text { sistem }\end{array}$ & $\begin{array}{l}\text { Kebutuhan } \\
\text { infrastrukkur } \\
\text { pendukung }\end{array}$ & $\begin{array}{c}\text { Konfigurasi hak akses } \\
\text { user pada sistem }\end{array}$ & $\begin{array}{l}\text { Detail time schedule } \\
\text { pernbangunan kode } \\
\text { program sistem }\end{array}$ & $\begin{array}{l}\text { Aturan proses } \\
\text { pembuatan kode } \\
\text { program (coding) }\end{array}$ \\
\hline $\begin{array}{l}\text { Function Enterprise } \\
\text { (Operation Classes) }\end{array}$ & $\begin{array}{c}\text { Pengisian data-data } \\
\text { atribut di setap tabel } \\
\text { entias }\end{array}$ & $\begin{array}{l}\text { Print ouf tampilan } \\
\text { Sisstem Informasi } \\
\text { Nanajemen Aset }\end{array}$ & $\begin{array}{c}\text { Konfiguras kebutuhan } \\
\text { hardware dan } \\
\text { sotware }\end{array}$ & $\begin{array}{c}\text { Dattar user yang } \\
\text { menggunakan sistem }\end{array}$ & $\begin{array}{c}\text { Time schedule } \\
\text { keseluruhan proyek } \\
\text { sistem }\end{array}$ & $\begin{array}{c}\text { Pebunjuk penggunaan } \\
\text { ftur-fitur dalam } \\
\text { sistem }\end{array}$ \\
\hline
\end{tabular}

Gambar 2. Perspektif planner 


\section{HASIL DAN PEMBAHASAN}

Hasil dari penelitian ini dapat dijelaskan sebagai berikut: (dengan beberapa tahapan penting dalam penjelasannya, sampai pada meghasilkan rekomendasi dan/atau blue print dalam mengatasi permasalahan serta memberikan solusi yang tepat)

\subsection{Perspektif Planner}

Tahap ini mendeskripsikan arsitektur secara kontekstual, dimana terdapat bisnis fungsional yang dapat dipetakan dalam tabel 1 berikut:

Tabel 1. Pemetaan perspektif Planner terhadap 6 abstraksi

\begin{tabular}{|c|c|c|}
\hline No & Abstraksi & Keterangan \\
\hline 1 & Data (What) & $\begin{array}{l}\text { Data pegawai, data supplier, data departemen, data lokasi, data kategori, } \\
\text { data barang, data aset barang, data pengadaan, data penempatan, data } \\
\text { peminjaman, data mutasi }\end{array}$ \\
\hline 2 & Fungsi (How) & $\begin{array}{l}\text { Proses pengadaan aset, proses penempatan aset, proses peminjaman aset, } \\
\text { proses pengembalian aset, roses mutasi aset }\end{array}$ \\
\hline 3 & Jaringan (Where) & Lokasi Rumah Sakit \\
\hline 4 & Orang (Who) & Kepala instalasi, bagian gudang, dan pengurus barang \\
\hline 5 & Waktu (When) & Spesifikasi proses manajemen aset \\
\hline 6 & Motivasi (Why) & Visi dan Misi Rumah Sakit \\
\hline
\end{tabular}

\subsection{Perspektif Owner}

Pada tahapan ini digambarkan dari sudut pandang pemilik atau orang yang bertanggung jawab penuh terhadap sistem informasi aset, dimana dijelaskan proses bisnis secara singkat dan kebutuhan sistem yang ingin dikembangkan [15]. Berikutnya adalah menggambarkan secara mendetails alur prosesnya, yang dapat dijelaskan pada gambar 3 berikut ini:

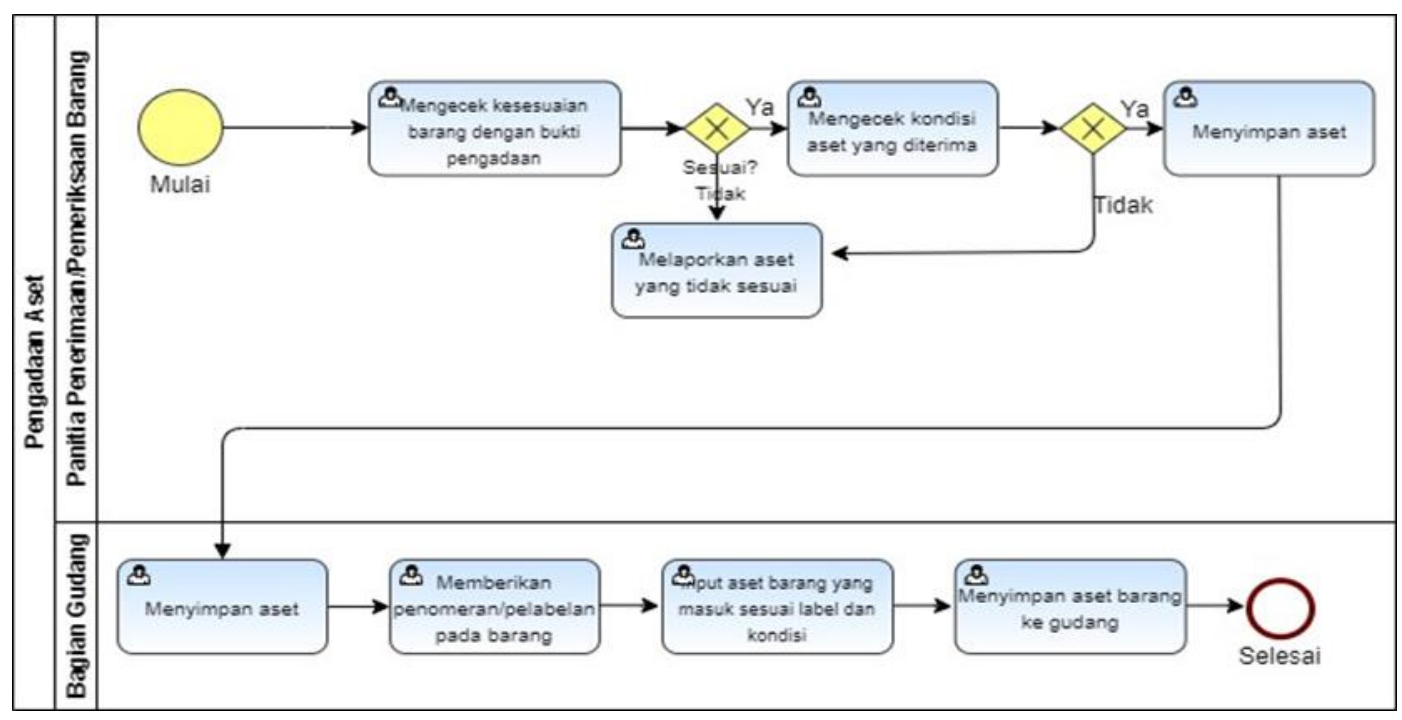

Gambar 3. BPMN pengadaan aset barang

Tahap berikutnya adalah menggambarkan denah rumah sakit (gambar 4), dan hal ini juga merupakan hal penting dalam menerapkan kerangka Zachman. Hal ini dapat digambarkan sebagai berikut: 


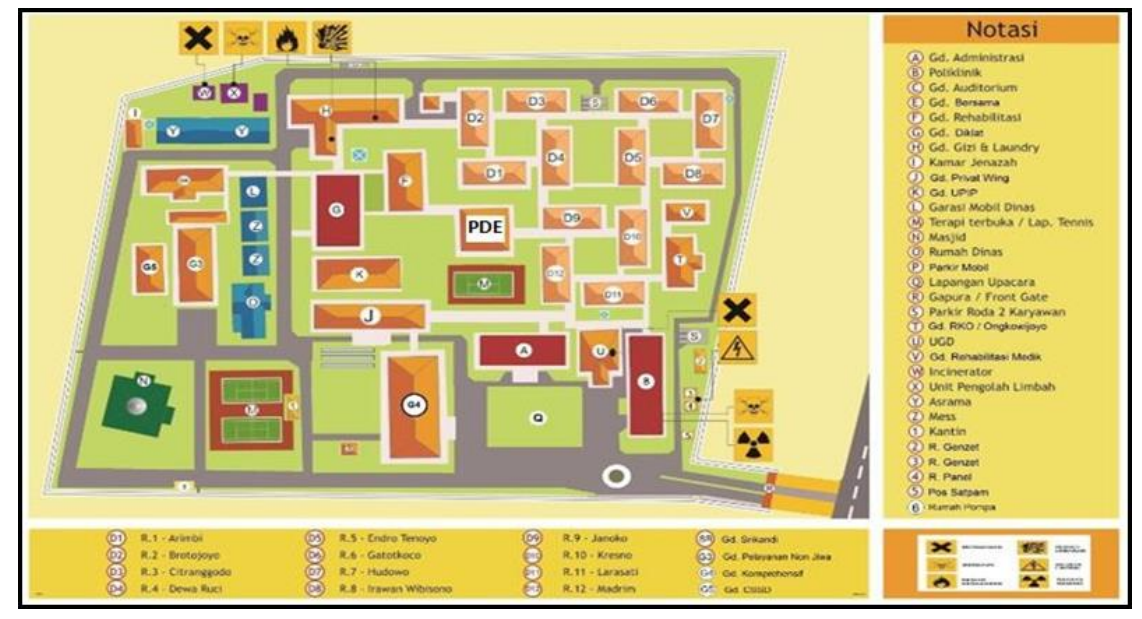

Gambar 4. Denah gedung pengolah data elektronik

Pada tahapan berikutnya, dijelaskan bahwa sumber daya manusia merupakan orangorang yang dipercaya dalam menganalisis, membangun dan mengelola sistem informasi manajemen aset. Masukan dari mereka akan dapat sangat berguna dalam mengembangkan sistemsistem yang dibutuhkan oleh rumah sakit. Oleh karena itu, jadwal pelaksanakan proyek tersebut harus tepat waktu. Hal ini dapat ditunjukkan dalam gambar 5 berikut:

\begin{tabular}{|c|c|c|c|c|c|c|c|c|c|c|c|c|c|c|c|c|c|c|}
\hline \multirow[b]{2}{*}{ No. } & \multirow[b]{2}{*}{ Program Kerja } & \multirow[b]{2}{*}{ Target Output } & \multicolumn{4}{|c|}{ Oktober 2019} & \multicolumn{4}{|c|}{ Novenber 2019} & \multicolumn{4}{|c|}{ Desember 2020} & \multicolumn{4}{|c|}{ Januari 2020} \\
\hline & & & 1 & 2 & 3 & 4 & 1 & 2 & 3 & 4 & 1 & 2 & 3 & 4 & 1 & 2 & 3 & 4 \\
\hline \multirow{3}{*}{1.} & \multirow{3}{*}{ Persiapan Proyek } & Mendefinisikan Masalah & & & & & & & & & & & & & & & & \\
\hline & & Mengumpulkan Data & & & & & & & & & & & & & & & & \\
\hline & & Menetapkan Jadwal Proyek & & & & & & & & & & & & & & & & \\
\hline \multirow{18}{*}{2.} & \multirow{18}{*}{$\begin{array}{l}\text { Fase Analisis dan } \\
\text { Penjabaran } 36 \text { Sel } \\
\text { Kerangka Zochmon }\end{array}$} & Analisis dan pendefinisian requirement & & & & & & & & & & & & & & & & \\
\hline & & dijabarkan ke dalam kolom whot, how, & & & & & & & & & & & & & & & & \\
\hline & & where, who, when, why & & & & & & & & & & & & & & & & \\
\hline & & Analisis dan pendefinisian requirement & & & & & & & & & & & & & & & & \\
\hline & & dijabarkan ke dalam kolom whot, how, & & & & & & & & & & & & & & & & \\
\hline & & where, who, when, why & & & & & & & & & & & & & & & & \\
\hline & & Analisis dan pendefinisian requirement & & & & & & & & & & & & & & & & \\
\hline & & $\begin{array}{l}\text { menurut sudut pandang designer yang } \\
\text { dijabarkan ke dalam kolom whot, how }\end{array}$ & & & & & & & & & & & & & & & & \\
\hline & & where, who, when, why & & & & & & & & & & & & & & & & \\
\hline & & Analisis dan pendefinisian requirement & & & & & & & & & & & & & & & & \\
\hline & & $\begin{array}{l}\text { menurut sudut pandang builder yang } \\
\text { dijabarkan ke dalam kolom whot, how, }\end{array}$ & & & & & & & & & & & & & & & & \\
\hline & & where, who, when, why & & & & & & & & & & & & & & & & \\
\hline & & Analisis dan pendefinisian requirement & & & & & & & & & & & & & & & & \\
\hline & & $\begin{array}{l}\text { menurut sudut pandang subcontroctor yang } \\
\text { dijabarkan ke dalam kolom whot, how, }\end{array}$ & & & & & & & & & & & & & & & & \\
\hline & & where, who, when, why & & & & & & & & & & & & & & & & \\
\hline & & Analisis dan pendefinisian requirement & & & & & & & & & & & & & & & & \\
\hline & & $\begin{array}{l}\text { menurut sudut pandang functioning yang } \\
\text { dijabarkan ke dalam kolom whot, how, }\end{array}$ & & & & & & & & & & & & & & & & \\
\hline & & where, who, when, why & & & & & & & & & & & & & & & & \\
\hline \multirow{3}{*}{3.} & \multirow{3}{*}{ Implementasi } & Membuat prototype aplikasi berdasarkan & & & & & & & & & & & & & & & & \\
\hline & & & & & & & & & & & & & & & & & & \\
\hline & & Mendapatkan prototype aplikasi & & & & & & & & & & & & & & & & \\
\hline
\end{tabular}

Gambar 5. Time schedule penelitian

Hal ini Terkait dengan perancangan dan pembangunan Sistem Informasi Manajemen Aset. Adapun tujuan-tujuannya adalah sebagai berikut: (1) Memberikan kemudahan pada Unit Pelaksana pengelola aset dalam mendukung pencapaian proses bisnis rumah sakit; (2) Memberikan kemudahan kepada setiap bagian terkait khususnya pada bagian pengelolaan aset 
dalam menjalankan tugas dan tanggung jawab; (3) Mengembangkan sistem yang user friendly sehingga lebih mudah untuk diakses tanpa mengenal lokasi dan waktu; (4) Meningkatkan keamanan penyimpanan data yang terotomatisasi; (5) Memberikan solusi kepada rumah sakit sehingga mampu untuk mendokumentasikan setiap proses yang dilakukan sistem.; (6) Memberikan kemudahan kepada Unit Pengelola Aset dan Pemimpin rumah sakit dalam memantau atau mengontrol ketercapaian seluruh proses bisnis yang diciptakan.

\subsection{Perspektif Designer}

Pada tahapan ini digambarkan use case (gambar 6) dan class diagram (gambar 7) untuk dapat menggambarkan sistem yang dikembangkan.

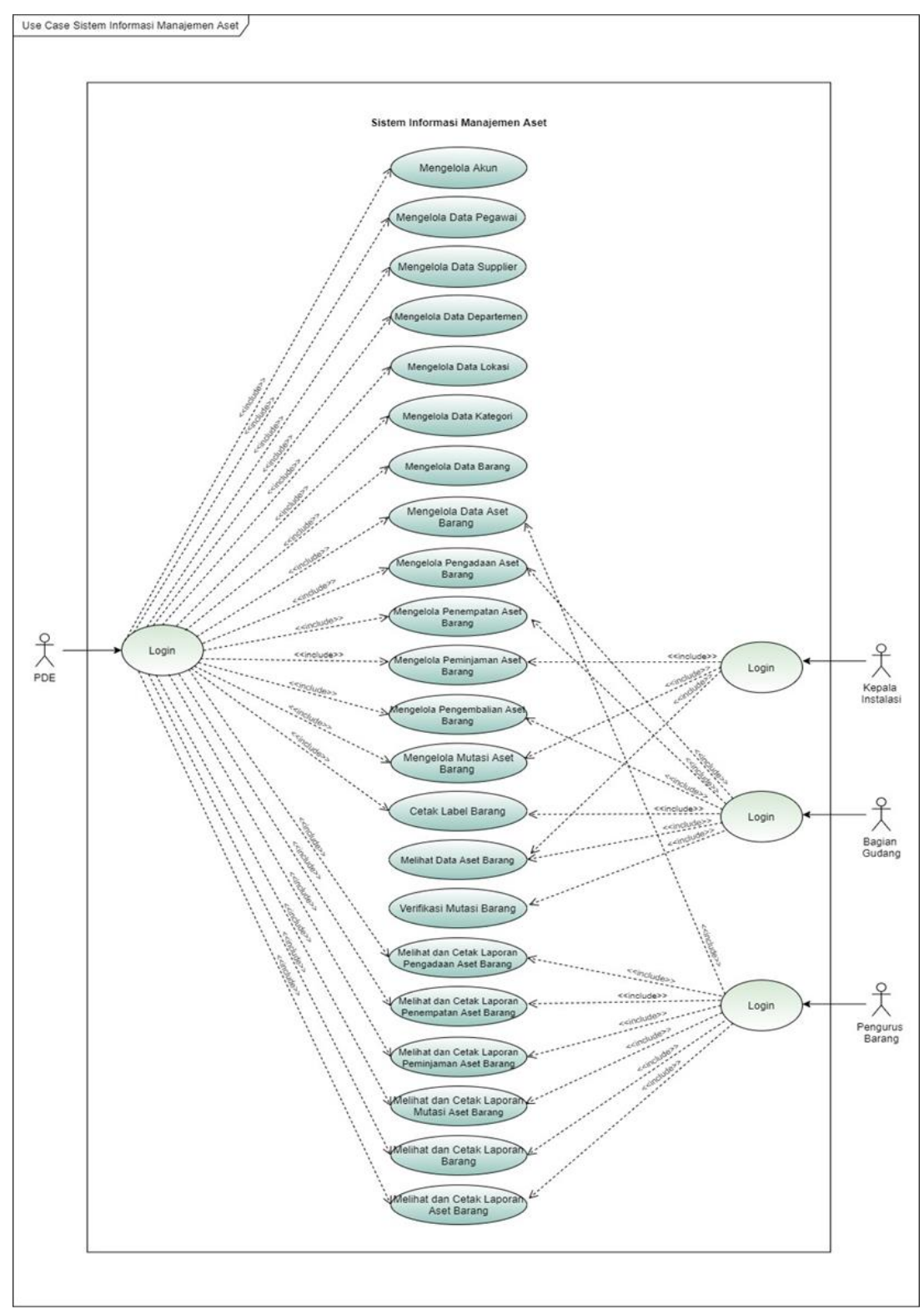

Gambar 7. Use case diagram sistem informasi manajemen aset 


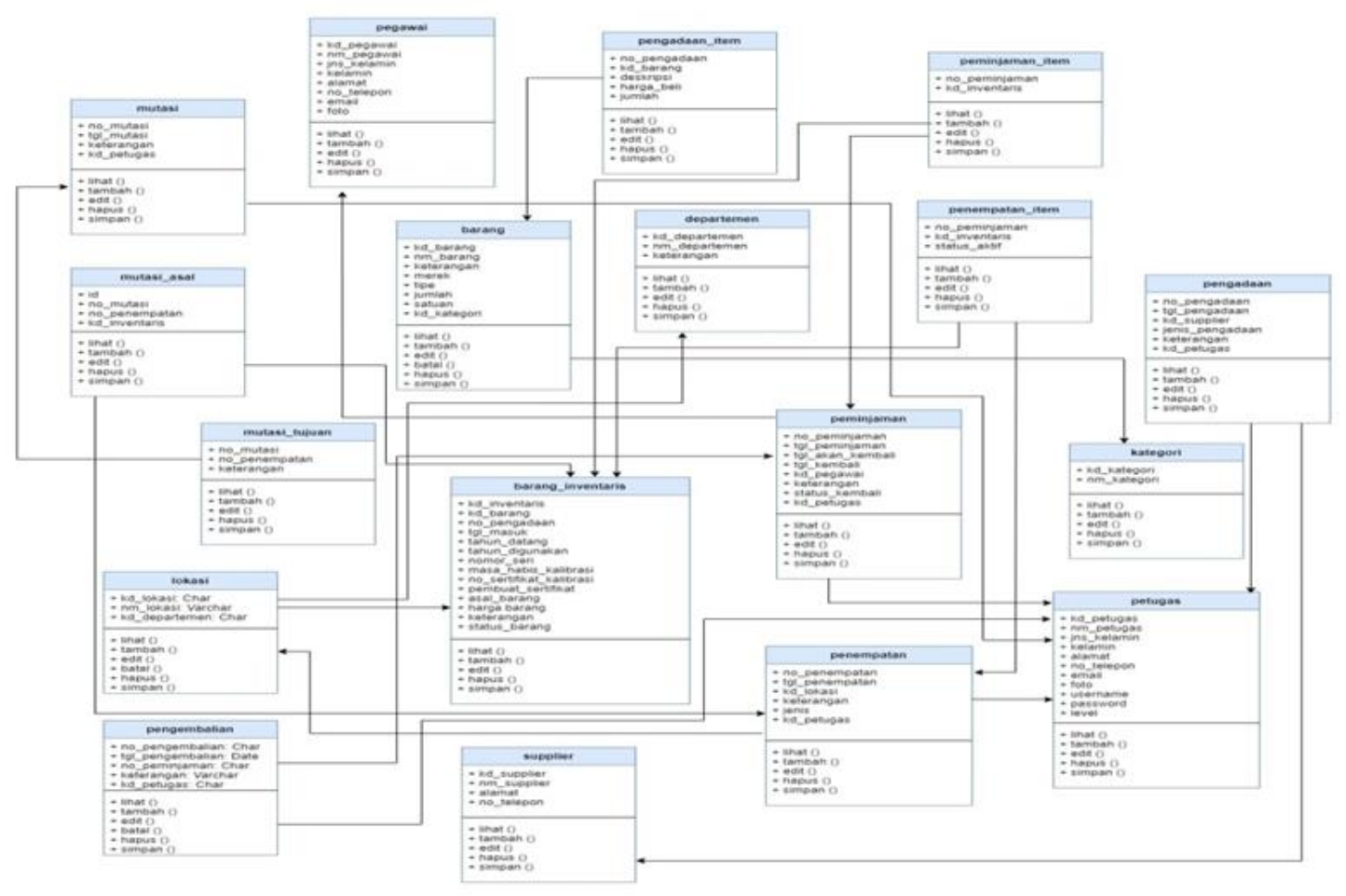

Gambar 6. Class Diagram

Tahap berikutnya adalah berdasarkan sudut pandang designer sel ini berisi skenario use case, activity diagram, dan sequence diagram. Hal ini dapat dijelaskan pada gambar 8 , sebagai berikut:

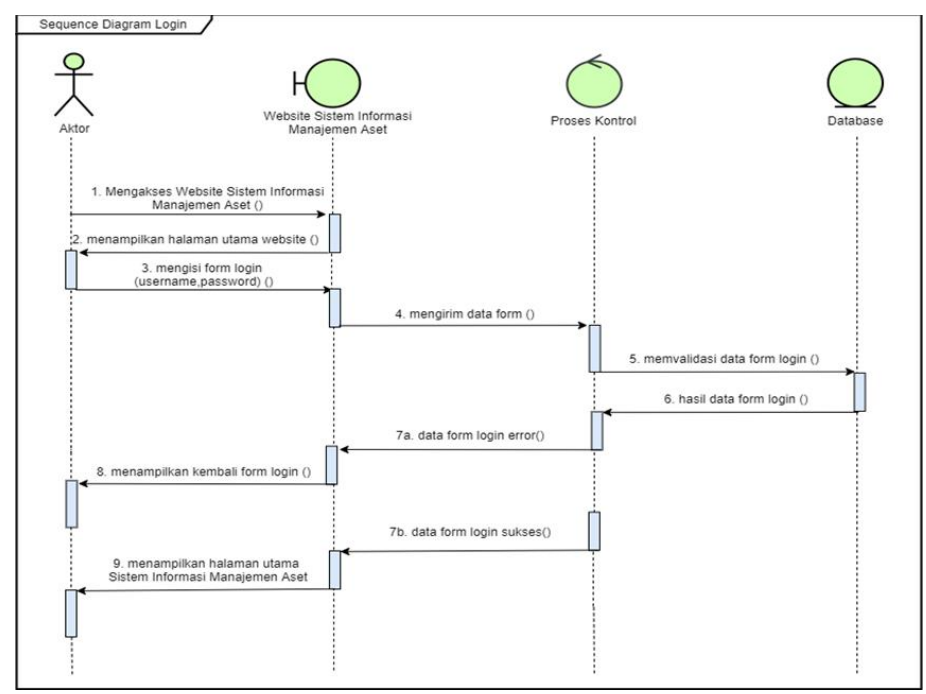

Gambar 8 Sequence Diagram

Tahap berikutnya adalah menggambarkan hubungan desain jaringan yang sudah dikembangkan oleh pengelola data elektornik. Di dalamnya berisikan desain input dan output secara manual yang digunakan sebagai acuan dalam mengembangkan sebuah sistem [16], [17]. Berikutnya adalah details jadwal yang sudah dijelaskan sebelumnya dan batasan-batasan dalam proses perancangan sistem manajemen aset yang akan diterapkan. 


\subsection{Perspektif Builder}

Pada tahapan ini dijelaskan bahwa terdapat alur proses bisnis yang dikembangkan dan terdapat empat entitas penting yang terlibat dalam manajemen aset, antara lain: PDE, kepala instalasi, Gudang dan pengurus barang. Pemetaan ini ditunjukkan dalam gambar 9 berikut:

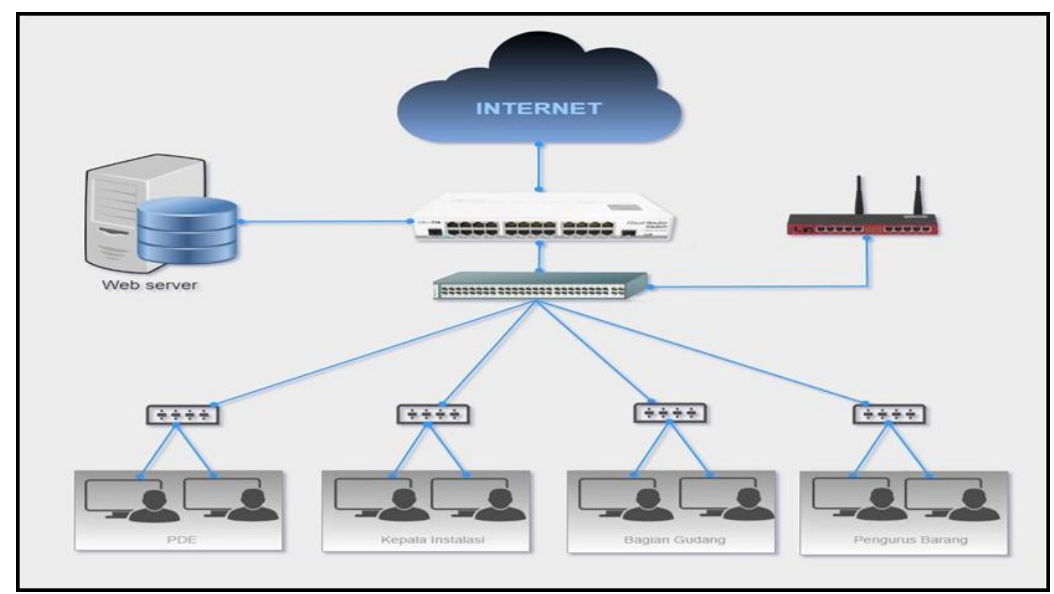

Gambar 9. Aristektur enterprise jaringan

Tahapan berikutnya adalah berhubungan dengan sebuah perancangan prototype, dimana digambarkan bahwa waktu atau jadwal yang digunakan untuk membangun sistem sebagai model aplikasi fisik, dimana desain pada perspektif sebelumnya digunakan secara optimal yaitu batasan teknologi, orang, biaya, dan waktu berdasarkan sudut pandang builder, Hal ini juga mengenai aturan dan batasan dalam membangun dan mengembangakan sistem berdasarkan desain yang telah dibuat.

\subsection{Perspektif Subcontractor}

Pada tahapan ini terdiri dari beberapa tahapan antara lain: digambarkan dalam bentuk rich pictures, dan details tersebut, ditunjukkan pada gambar 10 berikut:

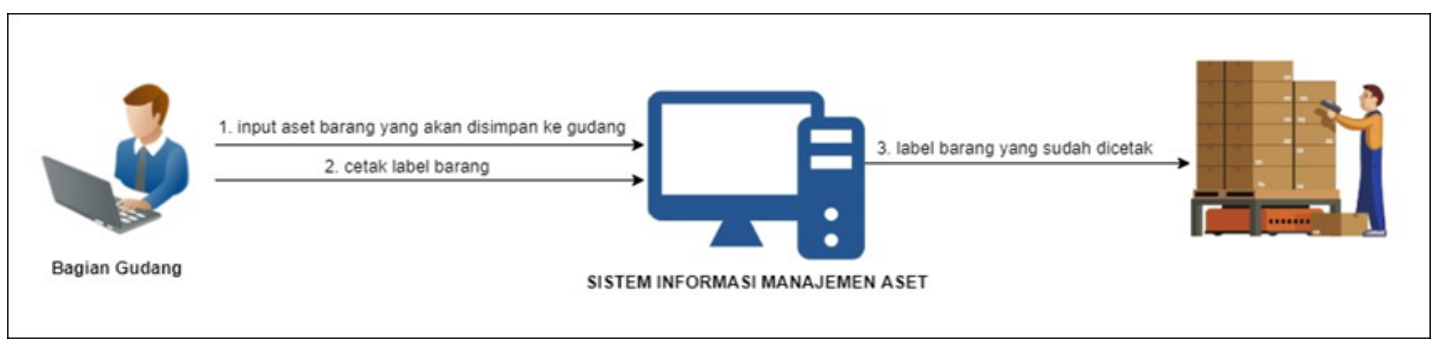

\section{Gambar 10 Rich picture}

Tahap berikutnya adalah: Pada tahap ini akan menjelaskan mengenai infrastruktur jaringan pendukung yang akan digunakan PDE dalam mengoperasikan sistem yang dibangun; Pengguna atau users dalam Sistem Informasi Manajemen Aset yang dikembangkan terdiri dari empat yaitu PDE, kepala instalsi, bagian gudang, dan pengurus barang; tahap ini menjelaskan mengenai time schedule atau jadwal yang dibutuhkan dalam menyusun algoritma kode program atau menyusun coding sehingga dihasilkan sistem menurut sudut pandang subcontractor; dan dalam membangun dan mengembangkan kode pemograman atau coding terdapat beberapa batasan ataupun aturan yang penting untuk diperhatikan berdasarkan perspektif subcontractor.

\subsection{Perspektif Function Enterprise}


Pada tahap ini berbagai macam panduan bagi user untuk menfungsikan system, melakukan manajemen operasi, dan mengevaluasi sistem yang di jelaskan pada tabel 2.

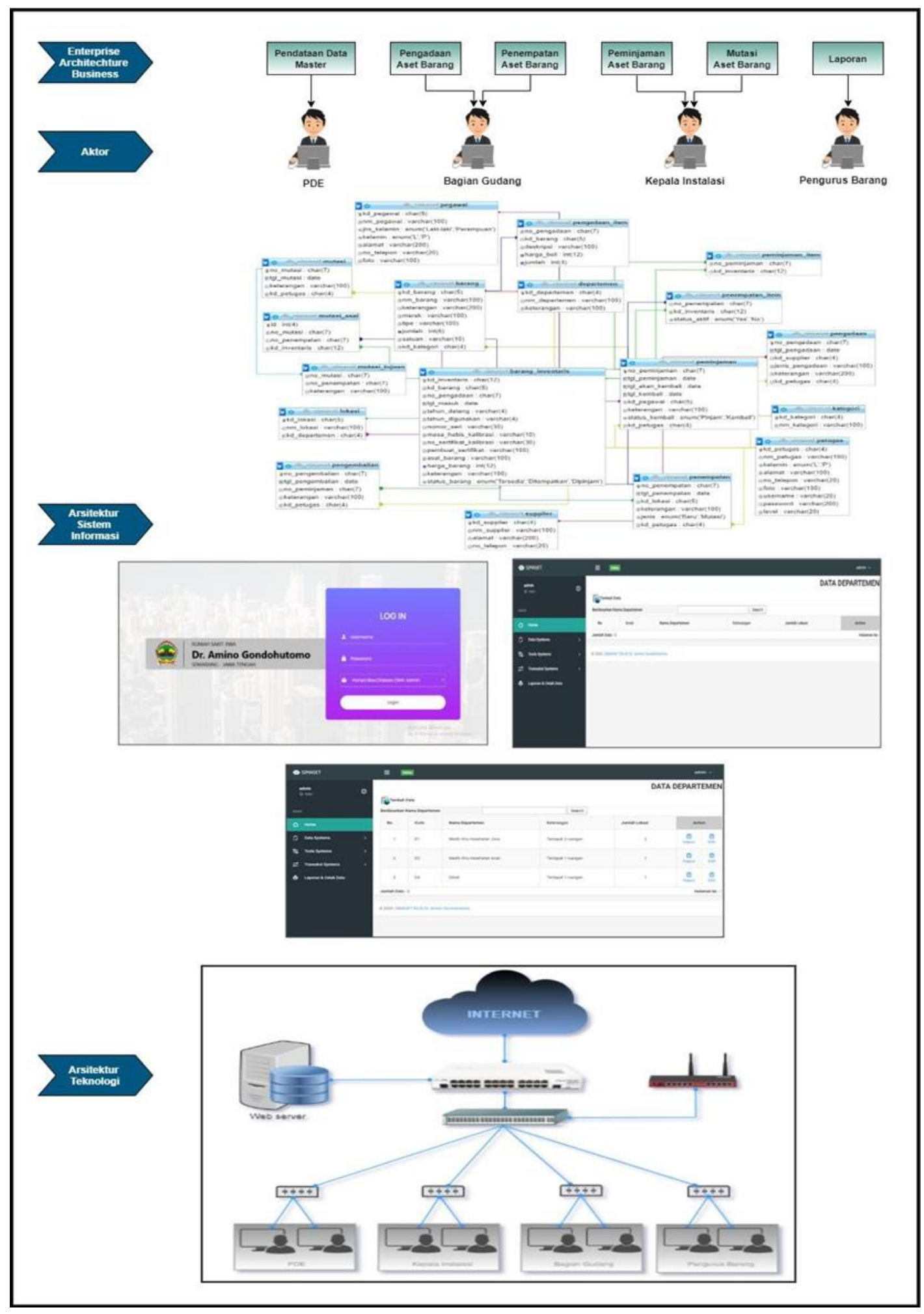

Gambar 11 Blueprint IT Sistem Informasi Manajemen Aset 
Tabel 2. Pemetaan perspektif Function Enterprise

\begin{tabular}{|c|c|c|}
\hline No & Abstraksi & Keterangan \\
\hline 1 & Data (What) & $\begin{array}{l}\text { Pada bagian ini ditampilkan data yang telah diisi ke dalam database dan hal } \\
\text { ini terkoneksi dengan prototype. Data ini diisi dengan data-data yang } \\
\text { dimiliki oleh rumah sakit dan bertambah sesuai dengan data-data baru yang } \\
\text { diinputkan }\end{array}$ \\
\hline 2 & Fungsi (How) & $\begin{array}{l}\text { Prototype yang dibangun telah dilakukan pengujian sehingga sesuai dengan } \\
\text { kebutuhan dan keinginan dari para stakeholders }\end{array}$ \\
\hline 3 & Jaringan (Where) & Konfigurasi kebutuhan hardware dan software \\
\hline 4 & Orang (Who) & Beberapa contoh user atau pengguna Sistem Informasi Manajemen Aset \\
\hline 5 & Waktu (When) & $\begin{array}{l}\text { Time Schedule pengembangan Sistem Informasi Manajamen Aset } \\
\text { secara keseluruhan }\end{array}$ \\
\hline 6 & Motivasi (Why) & Prosedur untuk mengakses Sistem Informasi Manajemen Aset \\
\hline
\end{tabular}

\subsection{Blueprint IT}

Pada tahap ini adalah merupakan tahap atau proses akhir, dimana pada gambar 11 diperolehlah suatu gambaran tentang blueprint IT pada sistem manajemen aset rumah sakit dan prototype berbasis Objected Oriented Programming yang dapat digunakan sebagai acuan untuk membangun, mengembangkan dan mendokumentasikan sistem. Gambar 11, merupakan tahapan dan hasil akhir dari proses analisis yang dilakukan pada rumah sakit. Pada blue print tersebut digambarkan beberapa tahapan penting, antara lain: alur proses dan actor, yang kemudian pada akhir proses, direkomendasikan prototype yang berguna untuk memberikan solusi kepada rumah sakit tersebut.

\section{KESIMPULAN}

Dari hasil pembahasan yang telah dilakukan maka dapat disimpulkan bahwa perancangan enterprise architecture systems yang dianalisis dengan menggunakan kerangka Zachman menghasilkan blue print yang dapat digunakan oleh PDE dalam mengembangkan sistem berikutnya. Prototype yang dihasilkan merupakan Sistem Informasi Manjamen Aset yang dibangun berdasarkan arsitektur data, fungsi, jaringan, sumber daya manusia, waktu, dan motivasi yang dilihat dari enam perspektif, yaitu planner, owner, designer, builder, subcontractor, dan function enterprise. Kerangka Zachman memberikan serangkaian solusi atas permasalahan yang ada pada rumah sakit, sehingga dapat menjadi rekomendasi baru guna untuk membantu proses pengambilan keputusan yang lebih mudah dan cepat. Hal tersebut ditunjukkan dengan adanya pemetaan terhadap setiap perspektif untuk dilakukan proses pendokumentasian terhadap setiap aktivitas dalam membangun sistem.

\section{SARAN}

Dari hasil penelitian yang disimpulkan pada sub sebelumnya, diharapkan dengan adanya penelitian ini dapat dimanfaatkan untuk penelitian selanjutnya sebagai bahan referensi penelitian. Berdasarkan penelitian yang telah dilakukan, beberapa saran yang diberikan untuk memperbaiki Sistem Informasi Manajemen Aset supaya lebih baik. Sistem dapat dikembangkan lagi ke dalam beberapa platform yang lebih luas seperti Sistem Informasi Manajemen Aset berbasis mobile agar lebih memudahkan pengguna dalam melakukan aktivitas pengelolaan aset. Hal ini akan menjadi lebih efektif apabila pada Sistem Manajemen Aset menjadi satu kesatuan tidak hanya aset barang melainkan aset tanah, bangunan, dan lain sebagainya. Penelitian berikutnya untuk melengkapi pada proses peminjaman aset, apabila aset tersebut tidak dikembalikan lebih dari tanggal jatuh tempo maka akan diberikan warning atau peringatan notifikasi pada sistem. 


\section{UCAPAN TERIMA KASIH}

Penulis mengucapkan terima kasih kepada pihak rumah sakit dan beberapa pihak yang telah membantu dalam menyelesaikan penelitian ini.

\section{DAFTAR PUSTAKA}

[1] A. Rojko, "Industry 4 . 0 Concept : Background and Overview," iJIM, vol. 11, no. 5, hal. 77-90, 2017.

[2] Ś. B, "INDUSTRY 4 . 0-ARE WE READY?," POLISH J. Manag. Stud., no. June, 2018, doi: $10.17512 /$ pjms.2018.17.1.19.

[3] J. Nagy, J. Oláh, E. Erdei, D. Máté, dan J. Popp, "The role and impact of industry 4.0 and the internet of things on the business strategy of the value chain-the case of hungary," Sustain., vol. 10, no. 10, 2018, doi: 10.3390/su10103491.

[4] K. Ridlan Ahmad, "Prototipe aplikasi manajemen sparepart atm menggunakan framework zachman pada logistik asp," Bangkit Indones., vol. VIII, no. 01, hal. 9-18, 2019.

[5] V. Rosalina, "Penerapan Zachman Framework Dalam Merancang Infrastruktur Jaringan Komputer Customer Relationship Management ( Crm ) Pada Universitas," J. prosisko, vol. 2, no. 2, 2015.

[6] F. Prakosa, "Information System Strategic Plan Using Zachman Framework and Raise at XYZ Vocational High School in Jakarta," I-Statement, vol. 4, no. 2, hal. 93-99, 2018.

[7] T. A. Nugraha, M. Imrona, dan E. Darwiyanto, "Pengembangan Sistem Informasi pada Perusahaan Dagang Menggunakan Zachman Framework Studi Kasus : Toko Perlengkapan Pesta Party Partner," Ind. J. Comput., vol. 4, no. August, hal. 1-8, 2019, doi: 10.21108/indojc.2019.4.2.254.

[8] M. A. Yaqin, F. Ade, A. Prayoga, A. N. Ihsan, dan F. Pulungan, "Arsitektur Enterprise pada Permainan Hay Day Menggunakan Metode Zachman Framework," in Seminar Nasional Inovasi dan Aplikasi Teknologi di Industri 2019, 2019, hal. 50-58.

[9] M. Ayundyahrini, S. Suprapto, F. Fahma, W. Soetopo, dan E. Pujiyanto, "Analisis Kebutuhan Teknis Stakeholder Pada Produk Kursi Roda Manual Menggunakan Zachman Framework," J. Ilm. Tek. Ind., vol. 18, no. 1, hal. 55-63, 2019, doi: 10.23917/jiti.v18i1.7771.

[10] V. Indra dan L. P. Dewi, "Enterprise Architecture Pada CV . Grande Zangrandi Dengan Metode Enterprise Architecture Planning ( EAP )," no. 121.

[11] L. Ertaul dan V. Rathod, "The Zachman Framework, the Owner's Perspective \&amp; Security."

[12] H. Sa'diyah, B. Soedijono, dan M. R. Arief, "Implementasi Framework Zachman Sebagai Salah Satu Metodologi Terstruktur Perancangan Learning Management System," Creat. Inf. Technol. J., vol. 6, no. 1, hal. 51, 2020, doi: 10.24076/citec.2019v6i1.243.

[13] V. Sergeev dan V. Solodovnikov, "Using an Adapted Zachman Framework for Enterprise Architecture in the Development of an Industry Methodology of Integrated Supply Chain Planning," Transp. Telecommun. J., vol. 21, no. 3, hal. 203-210, 2020, doi: 10.2478/ttj2020-0016.

[14] E. Lubis, R. Muninggar, B. H. Iskandar, dan J. Haluan, "the Socio-Economic Impacts of Nizam Zachman Oceanique Fishing Port Activities on the Community and Its Surrounding Environment," Malaysian J. Sci., vol. 39, no. 2, hal. 27-40, 2020, doi: 10.22452/mjs.vol39no2.2.

[15] Sfenrianto, G. Wang, H. Abdul, dan F. A. Nurul, "Comparative analysis of e-commerce and social media based trading in Indonesia," IOP Conf. Ser. Mater. Sci. Eng., vol. 237, hal. 012028, 2017, doi: 10.1088/1757-899X/237/1/012028.

[16] A. H. Setyawan, R. A. Atmaja, G. Wang, dan N. Legowo, "Designing effective E-learning system in Kanisius school with Zachman framework," Int. J. Adv. Trends Comput. Sci. 
Eng., vol. 9, no. 3, hal. 2619-2624, 2020, doi: 10.30534/ijatcse/2020/19932020.

[17] H. Tannady, J. F. Andry, B. G. Sudarsono, dan Y. Krishartanto, "Enterprise architecture using Zachman framework at paint manufacturing company," Technol. Reports Kansai Univ., vol. 62, no. 4, hal. 1869-1883, 2020. 